\title{
Intrinsic and Extrinsic Motivation in Physical Education Class and the Differences between Two Educational Pathways
}

\author{
Ricardo Ferraz a,b, ${ }^{\text {, }}$, Luís Branquinho a , Miguel Pereira a ${ }^{a}$ Mário C. Marques ${ }^{a, b}$, Henrique P. Neiva ${ }^{a, b}$,
} Daniel A. Marinho a,b

a Department of Sport Sciences, University of Beira Interior, Covilhã, 6201-001, Portugal.

${ }^{b}$ Research Center in Sports Sciences, Health Sciences and Human Development (CIDESD), Covilhã, 6201-001, Portugal.

*Corresponding author Email: ricardompferraz@gmail.com

DOI: https://doi.org/10.34256/ijpefs2138

Received: 07-07-2021, Revised: 04-08-2021; Accepted: 06-08-2021; Published: 13-08-2021

Abstract: This study aimed to determine the most and least important reasons for engaging in physical education classes among students in two educational pathways within the context of intrinsic and extrinsic motivation. Fortyone students participated in the study ( 25 males and 16 females; mean age $=16.37 \pm 0.829$ ). The sample was divided based on two class types: regular education and professional education. All students answered a questionnaire that aimed to verify the most and least important reasons for students to engage in physical education classes concerning intrinsic and extrinsic motivation. Indicated that both regular education and professional education classes had intrinsic and extrinsic motivation. The results also revealed that the participation of students was based essentially on their intrinsic motivation, but for different reasons when comparing the two educational pathways. Both types of the class were intrinsically and extrinsically motivated to participate in physical education classes.

Keywords: School, Regular Education, Professional Education, Exercise, Self-Determination

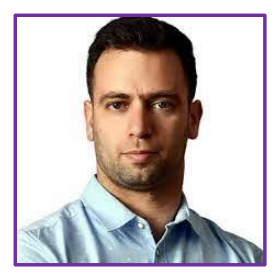

Ricardo Ferraz is graduated from University of Porto in Sport and Physical Education with a specialization in soccer sports training. He also was supported by a grant from the Science and Technology Foundation, concluding the Ph.D in Sport Sciences at University of Beira Interior with the maximum final grade of "Excellent". Currently he is assistant professor at University of Beira Interior and member of the Research Center in Sports Sciences, Health Sciences and Human Development. This research is recognized as relevant by the peers, as evidenced by the original articles published in highranked journals. In 2017, he was awarded the first prize by Portuguese Olympic Committee for the best scientific work in the field of Sports Training.

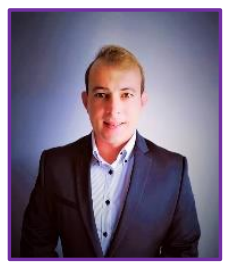

Luis Branquinho, is a $\mathrm{PhD}$ in Sports Science at the University of Beira Interior, who obtained the maximum final grade "Approved with Distinction". $\mathrm{He}$ has published several scientific articles and books in the field of Sports Science and his area of expertise is soccer training. He collaborated as a professor at the Department of Sports Science at the University of Beira Interior. He is currently a Professor, researcher and soccer coach, licensed and recognized by UEFA. In 2016 he received a research grant and won two prizes at the University of Beira Interior for his research project for his doctoral thesis.

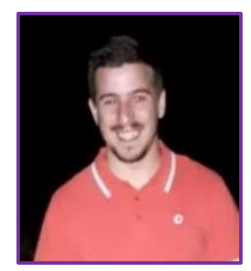

Miguel Pereira is a master student of Sports Science Department of University of Beira Interior.

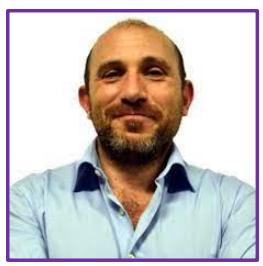

Mário C. Marques is the Head and full Professor of Training Theory and Methodology in the Department of Sports Sciences at the University of Beira Interior. He also holds an appointment as a Head of Strength and Conditioning performance analysis team of the CIDESD. Additionally, he is serving as Strength and 
Conditioning consultant for the Portuguese Swimming Federation. Collaborator in several funded projects focused on frailty and exercise to promote and recommend changes in lifestyle associated with physical exercise for frail patients at risk of functional decline and MID-FRAIL to test the efficacy of a multimodal intervention in prefrail/frail older patients. He has published more than 200 original articles in peer-reviewed journals and have been supervisor of more than $10 \mathrm{PhD}$ and approximately 50 Masters students.

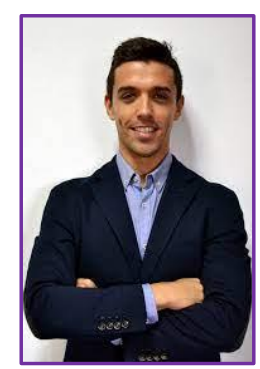

Henrique Pereira Neiva concluded his degree in Sport and Physical Education in the Faculty of Sport of University of Porto (FADE-UP), with the final grade of 16 . In 2015 finished Ph.D in in Sport Sciences at the University of Beira Interior and Research Center in Sport Sciences, Health Sciences and Human Development, with the thesis entitled "The effect of warm-up on swimming performance: the impact of volume, intensity and post warm-up recovery in elite swimmers", supported by a grant from the Science and Technology Foundation (SFRH/BD/74950/2010), and with the final grade of "Excellent", twenty (20) values. Member of Research Centre in Sports Sciences, Health Sciences and Human Development (CIDESD) and professor at University of Beira Interior, teaching graduate, master and doctoral students. He published more than 50 research documents, such as research papers in specialized journals and book chapters. Current area of research: training control and evaluation; warm-up and performance; resistance training and concurrent training.

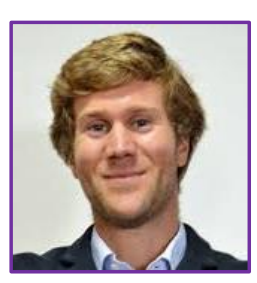

Daniel Marinho, Associate Professor with Aggregation at the Department of Sport Sciences at the University of Beira Interior. Graduated from the University of Porto (UP) in Sport and Physical Education in 2004 with Specialization in Sports Training. PhD in Sports Science from the University of Trás-os-Montes and Alto Douro (UTAD) in 2009. Head of the Research Center for Sports, Health and Human Development (CIDESD) and collaborator of the Portuguese Swimming Federation, within the scope of the Office of Training and Competition Assessment and Control (GACO/FPN). Research carried out within the scope of the assessment of sports performance, control and evaluation of training, highlighting the study of sports warming up in individual and collective sports, with recognized merit at national and international level.

\section{Introduction}

Physical education plays a fundamental role in students' integral development by enabling cognitive, psychomotor and affective development while also stimulating healthy lifestyles, socialisation, team spirit and sports practice [1]. The benefits of regular physical activity are diverse, including improvements in cardiovascular and respiratory function, decreased levels of anxiety and depression, increased sense of well-being and the development of cognitive and social valences [2-4]. These benefits were evidenced in a previous study [1] that defended the existence of significant contributions of physical activity to the education and development of children and young people in five domains (i.e., physical, lifestyle, affective, social and cognitive).

From a conceptual perspective, although physical education can be contested, it can be understood as a process elaborated on scientific bases that are pedagogically framed and oriented to guarantee the progressive development of child motor skills [5], because it may help children's make informed lifestyle choices and develop proficiency in movement skills $[6,7]$. Additionally, physical education must also facilitate knowledge of a wide variety of sports activities to promote their voluntary practice and consolidate active lifestyle habits that will last throughout the rest of their lives [8]. However, for this to occur, it is also important to deepen the concept of fundamental motivation. Motivation has been defined as a process that guides all forms of human activity through intrinsic and/or extrinsic factors to ensure persistence while developing a diversity of activities [9]. We considered that physical education represents the link between motivation and learning. Their performance determines the influence of motivation on students' success. Additionally, motivational and emotional variables play a crucial-if not the most vital-role in academic success $[10,11]$.

Motivation is conceptually approached from psychological and scientific perspectives [12]. Based on a vectorial magnitude defined in two dimensions: i) direction, which is understood as a need and purpose that answers why a subject engages in or avoids a specific type of activity; ii) intensity, which is understood as an impulse related to the degree of effort exhibited for a given behaviour as well as a clear 
link with the brain that presents the nervous system programmes that motivate behavioural manifestations [13]. Given the multiple theories of motivation in the literature, it is important to address two fundamental concepts of the present investigation: intrinsic motivation and extrinsic motivation.

Within the scope of a physical education class and its inherently pedagogically-oriented physical activities, students are intrinsically motivated by performing activities on their own through voluntary effort while deriving personal satisfaction without having any return beyond this [14]. Students regulate their behaviour in self-determined ways without the need for reinforcement or external reward. Since their will predominates at the expense of control, activities are sufficient for them because they involve great challenges and produce innate energy that allows students to experience pleasure and interest in an activity. On the other hand, in the school context, many of the students' activities are supported by extrinsic motivation, which is directly linked to external factors [15]. This occurs when participation in an activity works within a reward or punishment system since there is an awareness that a benefit can be withdrawn to avoid difficulties [16].

A recent study that compared the two concepts of motivation inferred that intrinsic motivation was the most important for students. In fact, the students stated that they were motivated more by internal factors and that the physical education class was a way to seek their own well-being through activities that they enjoyed and learning new content and skills [17]. These results were corroborated through another investigation [18] carried out with a sample of 30 high school students that used the Kobal questionnaire (1996) [19] as an instrument. In this study, the students surveyed were more intrinsically motivated than extrinsically motivated for physical education classes.

Yet, a previous study [20], which investigated the motivation in physical education classes in elementary school, revealed that students' demotivation in classes intensifies after the 6th year of elementary school, which emphasizes the importance of investigating both motivation types (i.e., intrinsic and extrinsic) of students at older ages. However, several studies carried out in different regions have found that in relation to the motivation associated with physical education classes in high school students, there was a growing lack of interest throughout the school path of most students [21-23]. This data shows that, with the progress of the students' school path, the contents and contexts are not sufficiently motivating. This idea is corroborated through a study [24] in which it was concluded that declines in the intrinsic motivation for the task, were associated with the decreased satisfaction of psychological needs. Furthermore, another investigation [25] that used a questionnaire based and adapted from Darido [26] concluded the students considered the factor responsible for extrinsic demotivation the contents that are they repeat each class, and that teachers only work with ball sports (i.e., games like soccer, volleyball), as they are more media-oriented sports, neglecting approaches to other modalities (i.e., judo, gymnastics, among others). The lack of motivating strategies ends up reaching teachers who observe the growing lack of interest and do not find ways to reverse the situation and motivate students [27]. Thus, although there are some studies on the topic of investigation [28-30], there remains a need for more research to clarify the motivational indicators of students in different contexts.

Since physical education is mandatory for most students between the $5^{\text {th }}$ and $12^{\text {th }}$ years of schooling, it is assumed that it is contextually different from sports practice, which involves the choice of an individual having a higher index of initial self-determination.

Thus, the need to answer relevant questionssuch as those related to the impact of motivation and whether or not it drives engagement in physical education classes-becomes relevant. In this sense, pertinent questions aim to understand whether physical education classes motivate students and teachers, whether their teaching methods and curriculums are sufficiently stimulating, motivating and adjusted for students. This study is justified based on the reflective socio-professional dimension (as a field of interest) of the existing knowledge actually at the levels of intrinsic and extrinsic motivation among students who participate in physical education classes, as well as their use of the content taught in determining whether there are differences between two educational pathways (i.e., regular education and professional education). Therefore, the main objective of this study was to determine the most and least important reasons for students of both types of the educational pathway (i.e., professional and regular) to engage in a physical education class, with regard to intrinsic and extrinsic motivation. 


\section{Materials and Methods}

\subsection{Participants}

A group of 41 students from a European school ( 25 male and 16 female; mean age $=16.37 \pm 0.829$ ) participated in the present study. The sample was divided based on class type (i.e., regular education or professional education). Regular education is characterized as an educational path aimed at integration into university education or to acquire minimum compulsory education. Professional education is characterized as an educational path aimed at integration into the labour market, and its completion attributes a professional qualification. The regular education class consisted of 20 students ( 6 male and 14 female; age $=16.7 \pm 0.571$ ) and the professional education class consisted of 21 students (19 male and 2 female; age $=16.05 \pm 0.921$ )

All participants and the teacher were informed verbally and in writing regarding the nature of the study. They were also informed that they could withdraw from the study at any time, even after giving their written consent. All parents provided their informed consent to allow the voluntary participation of their children in the study. The present study had the approval of the Academy's Ethical Advisory Commission and was conducted in accordance with the Declaration of Helsinki.

\subsection{Experimental Design}

This study aimed to determine the most and least important reasons for students of both types of education (i.e., professional and regular) for engaging in a physical education class with regard to intrinsic and extrinsic motivation. An observational study design was used with data collected through a cross-sectional questionnaire consisting of 32 questions. The questionnaire was provided to the students at the end of a physical education class. All experimental procedures were performed in coordination with the teachers and did not cause any changes in students' routines.

\subsection{Procedures}

The research team developed the questionnaire in consultation with 5 experts in the field of Sport Sciences (cumulatively, they were academic researchers and teachers at different levels of education) and was designed to verify students' extrinsic and intrinsic motivations for a physical education class. A theoretical framework was used to design the questionnaire, as described by Meira [31]. Adjustments were made to make the instrument's statements clearer and more relevant to the case. Similar procedures have been used in other similar studies [31]. According to previously described methods, a pilot test questionnaire was carried out with ten students before the study started to provide facial validity and guarantee its suitability for use in this population [31]. The feedback resulting from this pilot test was used to refine the questionnaire questions and to improve the current terminology regarding motivation (no data from the pilot study was used as part of this investigation). Each expert was asked to establish the adequacy of the issues and to identify inappropriate wording or ambiguities. They had to classify the degree of agreement regarding the inclusion / exclusion of the statements of the motivation characterization instrument for physical education classes using a 5-point Likert scale from 1 (Strongly disagree) to 5 (Strongly agree), similar as previously suggested [32]. The questionnaire presented to the students consisted of 3 dimensions of questions for extrinsic and intrinsic motivation as well as 32 statements (16 referring to intrinsic motivation and 16 referring to extrinsic motivation).

Before applying the questionnaire, students were informed that they could only answer questions with a single answer and that they should answer according to what they liked to do in physical education classes and what they would like to do.

In this study, Cronbach's coefficient a was also used to calculate the internal consistency coefficients of the items included in the questionnaire [33]. For the overall reliability, the Cronbach's alpha value was 0.85 and the reliability coefficient a obtained for each dimension varied between 0.71 and 0.96 , indicating this modified version's satisfactory level of internal consistency. Consequently, it was considered adequate to measure the motivations of physical education students according to the purpose of the study.

\subsection{Statistical analysis}

The verification of intrinsic and extrinsic motivation trends was performed through descriptive statistical analysis. Thus, a table of frequencies was prepared considering agreement or disagreement with each of the 32 statements (i.e., each item of the 3 studied questions). Values below 3 were deemed to be concordant, while values above 3 were considered a 
disagreement. This method considers the arithmetic mean of the scores obtained and the frequency of responses attributed to each item.

The survey results were grouped and processed to analyse respondents' answers. The absolute and relative frequencies of students' answers to each of the questions were analysed. Fisher's exact test was used to compare two groups of independent samples to test whether the row variable and the column variable were independent. Cramer's $\mathrm{V}$ was used to quantify the association between variables. The degree of association was classified based on the following criteria: $0<\mathrm{V}<0.1$ : very weak association; $0.1 \leq \mathrm{V}<0.3$ : weak association; $0.3 \leq \mathrm{V}<0.5$ : moderate association; $V \geq 0.5$ : strong association [34]. Due to the characteristics of the sample, a $p$-value of 0.01 was used.

\section{Results}

Table 1 presents the results for students' physical activity outside the physical education class. The data revealed that $46.35 \%$ of the students practised federated sport. This includes students who competitively practised sport in competitions outside the school. Only $10 \%$ of students practised federated sport in the regular education class, whereas this practice had a higher incidence in professional education class (85\%). It was also noted that fewer students participated in school sports than federated sports. Only $21.29 \%$ of the total sample participated in school sports groups, representing $5 \%$ of students in the regular class and $28 \%$ in the professional class.
Upon comparing regular education with professional education, it was concluded that the professional education class had greater participation in physical activity outside of the physical education class. However, in both, the percentage of practitioners is lower than the percentage of non-practitioners.

The analysis in Table 2 presents the level of satisfaction among students regarding physical education class. The results presented in Table 3 show that $51.22 \%$ of students like physical education and $39.02 \%$ like physical education a lot. However, $4.88 \%$ stated that they do not like physical education and $4.88 \%$ stated that they are indifferent. Comparing the types of education, it can be concluded that professional students like physical education more than regular education students and that $20 \%$ of regular education students do not like it or said it was indifferent. Notably, no professional education students mentioned not liking the discipline or that they were indifferent.

\subsection{Intrinsic motivation survey}

Table 3 presents data related to the reasons (i.e., which is intrinsic motivation) for participating in physical education classes. It was found that both studied groups noted a taste for physical activity as a reason for their participation since the proportion of combined 'strongly agree' and 'agree' responses was $95 \%$ and $100 \%$ in the regular and professional education groups, respectively. Additionally, only one regular education student revealed doubts.

Table 1. Physical activity outside of the physical education class.

\begin{tabular}{lllllllll}
\hline & \multicolumn{1}{c}{ School Class } \\
\hline & & Total \% (n) & \multicolumn{3}{l}{ Regular \% (n) } & \multicolumn{1}{l}{ Professional \% (n) } \\
\hline \multirow{2}{*}{ Federated Sport } & & & M & F & Total & M & F & Total \\
\cline { 2 - 10 } & Yes & $46.35(19)$ & 0 & 2 & $10(2)$ & 16 & 1 & $85(17)$ \\
\cline { 2 - 9 } School Sport & $53.65(22)$ & 6 & 12 & $90(18)$ & 3 & 1 & $15(4)$ \\
\cline { 2 - 9 } & Yes & $21.95(9)$ & 0 & 1 & $5(1)$ & 7 & 1 & $38.10(8)$ \\
\cline { 2 - 9 } & No & $78.05(32)$ & 6 & 13 & $95(19)$ & 12 & 1 & $61.9(13)$ \\
\hline
\end{tabular}

Note: $\mathrm{M}=$ Male; F=Female.

Table 2. Values of relative and absolute frequencies for the question Do you like physical education?

\begin{tabular}{lllllll}
\hline & & $\begin{array}{l}\text { I don't like it } \\
\text { \%(n) }\end{array}$ & $\begin{array}{l}\text { I like it a little } \\
\mathbf{\% ( n )}\end{array}$ & $\begin{array}{l}\text { Indifferent } \\
\mathbf{\% ( n )}\end{array}$ & $\begin{array}{l}\text { I like it } \\
\text { \%(n) }\end{array}$ & $\begin{array}{l}\text { I like it a lot } \\
\text { \%(n) }\end{array}$ \\
\hline \multirow{2}{*}{$\begin{array}{l}\text { School } \\
\text { Class }\end{array}$} & Regular & 0 & $10(2)$ & $10(2)$ & $60(12)$ & $20(4)$ \\
\cline { 2 - 7 } & Professional & 0 & 0 & 0 & $42.86(9)$ & $57.14(12)$ \\
\hline & Total & 0 & $4.88(2)$ & $4.88(2)$ & $51.22(21)$ & $39.02(16)$ \\
\hline
\end{tabular}


Table 3. Values of relative and absolute frequencies for the question 'A1. I participate in physical education classes because:'

\begin{tabular}{|c|c|c|c|c|c|c|}
\hline Items & 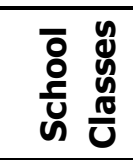 & $\begin{array}{c}\text { Strongly } \\
\text { Agree }\end{array}$ & Agree & $\begin{array}{l}\text { I am in } \\
\text { Doubt }\end{array}$ & Disagree & $\begin{array}{l}\text { Strongly } \\
\text { Disagree }\end{array}$ \\
\hline \multirow[t]{2}{*}{ 1. I like physical activities. } & $\mathrm{R}$ & $5(25 \%)$ & $14(70 \%)$ & $1(5 \%)$ & 0 & 0 \\
\hline & $P$ & $17(81 \%)$ & $4(19 \%)$ & 0 & 0 & 0 \\
\hline \multirow{2}{*}{$\begin{array}{l}\text { 2. The classes give me } \\
\text { pleasure. }\end{array}$} & $\mathrm{R}$ & $2(10 \%)$ & $11(55 \%)$ & $6(30 \%)$ & $1(5 \%)$ & 0 \\
\hline & $P$ & $10(47.6 \%)$ & $10(47.6)$ & 0 & 0 & $1(4.8 \%)$ \\
\hline \multirow[t]{2}{*}{ 3. I like to learn new skills. } & $\mathrm{R}$ & $3(15 \%)$ & $13(65 \%)$ & $3(15 \%)$ & 0 & $1(5 \%)$ \\
\hline & $P$ & $15(71.4 \%)$ & $5(23.8 \%)$ & $1(4.8 \%)$ & 0 & 0 \\
\hline \multirow{2}{*}{$\begin{array}{l}\text { 4. I think it is important to } \\
\text { increase my knowledge about } \\
\text { sports and other content. }\end{array}$} & $\mathrm{R}$ & $15(75 \%)$ & $2(10 \%)$ & $3(15 \%)$ & 0 & 0 \\
\hline & $P$ & $18(85.71 \%)$ & $3(14.29 \%)$ & 0 & 0 & 0 \\
\hline \multirow{2}{*}{ 5. I feel healthy with classes. } & $\mathrm{R}$ & $6(30 \%)$ & $13(65 \%)$ & 0 & $1(5 \%)$ & 0 \\
\hline & $\mathrm{P}$ & $14(66.7 \%)$ & $4(19 \%)$ & $2(9.5 \%)$ & $1(4.8 \%)$ & 0 \\
\hline
\end{tabular}

Note: $\mathrm{R}=$ Regular; $\mathrm{P}=$ Professional.

Table 4. Values of Fisher's exact test and Cramer's V for the question 'A1. I participate in physical education classes because:'

1. I like physical activities.

\begin{tabular}{|c|c|c|}
\hline $\begin{array}{l}\text { Fisher's } \\
\text { value }\end{array}$ & p- & $\begin{array}{l}\text { Cramer's } \\
\text { V }\end{array}$ \\
\hline .001 & & .565 \\
\hline .003 & & .571 \\
\hline .001 & & .575 \\
\hline
\end{tabular}

2. The classes give me pleasure.

3. I like to learn new skills.

001

.575 other content.

5. I feel healthy with classes.

.006

.493

Table 5. Values of relative and absolute frequencies for the question 'A2. I like physical education classes when:'.

\begin{tabular}{|c|c|c|c|c|c|c|}
\hline Items & $\begin{array}{l}\bar{y} \\
\overline{0} \\
\frac{y}{y} \\
\bar{y} \\
\bar{n}\end{array}$ & $\begin{array}{l}\text { Strongly } \\
\text { Agree }\end{array}$ & Agree & $\begin{array}{l}\text { I am in } \\
\text { Doubt }\end{array}$ & Disagree & $\begin{array}{l}\text { Strongly } \\
\text { Disagree }\end{array}$ \\
\hline \multirow{2}{*}{ 1. I learn a new skill. } & $\mathrm{R}$ & $10(50 \%)$ & $9(45 \%)$ & 0 & $1(5 \%)$ & 0 \\
\hline & $\mathrm{P}$ & $12(57.1 \%)$ & $6(28.6 \%)$ & $2(9.5 \%)$ & $1(4.8 \%)$ & 0 \\
\hline \multirow{2}{*}{$\begin{array}{l}\text { 2. I fully dedicate myself to the } \\
\text { activity. }\end{array}$} & $\mathrm{R}$ & $7(35 \%)$ & $9(45 \%)$ & $2(10 \%)$ & $1(5 \%)$ & $1(5 \%)$ \\
\hline & $\mathrm{P}$ & $11(52.3 \%)$ & $9(42.9 \%)$ & $1(4.8 \%)$ & 0 & 0 \\
\hline \multirow{2}{*}{$\begin{array}{l}\text { 3. I understand the benefits of } \\
\text { the activities proposed in class. }\end{array}$} & $\mathrm{R}$ & $10(50 \%)$ & $8(40 \%)$ & $1(5 \%)$ & 0 & $1(5 \%)$ \\
\hline & $\mathrm{P}$ & $12(57.1 \%)$ & $8(38.1 \%)$ & $1(4.8 \%)$ & 0 & 0 \\
\hline \multirow{2}{*}{ 4. Activities give me pleasure. } & $\mathrm{R}$ & $6(30 \%)$ & $11(55 \%)$ & $2(10 \%)$ & 0 & $1(5 \%)$ \\
\hline & $P$ & $10(47.6 \%)$ & $8(38.1 \%)$ & $2(9.5 \%)$ & 0 & $1(4.8 \%)$ \\
\hline \multirow{2}{*}{$\begin{array}{l}\text { 5. What I learn makes me want } \\
\text { to practice more. }\end{array}$} & $\mathrm{R}$ & $7(35 \%)$ & $7(35 \%)$ & $4(20 \%)$ & $1(5 \%)$ & $1(5 \%)$ \\
\hline & $P$ & $11(52.4 \%)$ & $8(38.1 \%)$ & $2(9.5 \%)$ & 0 & 0 \\
\hline \multirow{2}{*}{ 6. Move my body. } & $\mathrm{R}$ & $8(40 \%)$ & $11(55 \%)$ & $1(5 \%)$ & 0 & 0 \\
\hline & $\mathrm{P}$ & $14(66.7 \%)$ & $5(23.8 \%)$ & $2(9.5 \%)$ & 0 & 0 \\
\hline
\end{tabular}

Note: $\mathrm{R}=$ Regular; $\mathrm{P}=$ Professional. 
Table 6. Values for Fisher's exact test and Cramer's V for the question 'A2. I like physical education classes when:'.

\begin{tabular}{lll}
\hline & Fisher's p-value & Cramer's V \\
\hline 1. I learn a new skill. & .542 & .259 \\
\hline 2. I fully dedicate myself to the activity. & .582 & .279 \\
\hline 3. I understand the benefits of the activities proposed in class. & .933 & .168 \\
\hline 4. Activities give me pleasure. & .734 & .188 \\
\hline 5. What I learn makes me want to practice more. & .448 & .296 \\
\hline 6. Move my body. & .115 & .320 \\
\hline
\end{tabular}

Table 7. Values of relative and absolute frequencies for the question 'A3. I don't like physical education classes when:'.

\begin{tabular}{|c|c|c|c|c|c|c|}
\hline Items & $\begin{array}{l}\overline{8} \\
\frac{0}{y} \\
\frac{0}{0} \\
\text { u }\end{array}$ & $\begin{array}{l}\text { Strongly } \\
\text { Agree }\end{array}$ & Agree & $\begin{array}{l}\text { I am in } \\
\text { Doubt }\end{array}$ & Disagree & $\begin{array}{l}\text { Strongly } \\
\text { Disagree }\end{array}$ \\
\hline \multirow{2}{*}{$\begin{array}{l}\text { 1. I can't do the activities } \\
\text { well. }\end{array}$} & $\mathrm{R}$ & $2(10 \%)$ & $9(45 \%)$ & $1(5 \%)$ & $5(25 \%)$ & $3(15 \%)$ \\
\hline & $\mathrm{P}$ & $1(4.8 \%)$ & $11(52.4 \%)$ & $4(19 \%)$ & $4(19 \%)$ & $1(4.8 \%)$ \\
\hline \multirow{2}{*}{$\begin{array}{l}\text { 2. I do not feel pleasure in } \\
\text { the proposed activity. }\end{array}$} & $\mathrm{R}$ & $4(20 \%)$ & $7(35 \%)$ & $2(10 \%)$ & $3(15 \%)$ & $4(20 \%)$ \\
\hline & $\mathrm{P}$ & $4(19 \%)$ & $7(33.3 \%)$ & $6(28.6 \%)$ & $3(14.3 \%)$ & $1(4.8 \%)$ \\
\hline \multirow{2}{*}{$\begin{array}{l}\text { 3.I almost do not have the } \\
\text { opportunity to play. }\end{array}$} & $\mathrm{R}$ & $3(15 \%)$ & $7(35 \%)$ & $2(10 \%)$ & $4(20 \%)$ & $4(20 \%)$ \\
\hline & $\mathrm{P}$ & $4(19 \%)$ & $6(28.6 \%)$ & $5(23.8 \%)$ & $4(19 \%)$ & $2(9.5 \%)$ \\
\hline \multirow{2}{*}{$\begin{array}{l}\text { 4. I exercise my body a } \\
\text { little. }\end{array}$} & $R$ & $2(10 \%)$ & $7(35 \%)$ & $5(25 \%)$ & $1(5 \%)$ & $5(25 \%)$ \\
\hline & $\mathrm{P}$ & $3(14.3 \%)$ & $5(23.8 \%)$ & 7 (33.3\%) & $2(9.5 \%)$ & $4(19 \%)$ \\
\hline \multirow{2}{*}{$\begin{array}{l}\text { 5.There is no time to } \\
\text { practice everything you } \\
\text { would like. }\end{array}$} & $\mathrm{R}$ & $3(15 \%)$ & $8(40 \%)$ & $6(30 \%)$ & $1(5 \%)$ & $2(10 \%)$ \\
\hline & $\mathrm{P}$ & $5(23.8 \%)$ & $9(42.9 \%)$ & $2(9.5 \%)$ & $2(9.5 \%)$ & $3(14.3 \%)$ \\
\hline
\end{tabular}

Note: $\mathrm{R}=$ Regular; $\mathrm{P}=$ Professional.

Table 8. Values of Fisher's exact Test and Cramer's V in the question 'A3. I don't like physical education classes when:'.

1. I can't do the activities well.

\begin{tabular}{ll} 
Fisher's p-value & V de Cramer \\
.562 & .289 \\
.460 & .304 \\
.763 & .229 \\
.882 & .177 \\
.632 & .274 \\
\hline
\end{tabular}

Moreover, the pleasure that physical education classes provided to students were the main reason for students in professional education choosing the options 'strongly agree' and 'agree' with reference to this point justifying their participation in the class. However, the same did not occur for students in the regular education class since their answers were divided between the various options: $10 \%$ strongly agree, $55 \%$ agree, $30 \%$ in doubt and $1 \%$ disagree.

When the taste for learning new skills in professional education was analysed, $95.2 \%$ of these students 'strongly agreed' or 'agreed' that this was the reason for their participation, with only one student in doubt on this point. Regular education divided its options: $80 \%$ of the class 'agreed a lot' or 'agreed' that this was the reason for their participation; however, $15 \%$ of the class had doubts and $5 \%$ (1 student) refused, even though this was the reason for their participation.

In both groups, when the reason presented was the importance of students' knowledge about sports and other content, the answers essentially focused on' strongly agree' and 'agree' options. The same tendency of responses was observed for the 
question of whether students felt healthy due to physical education classes.

Most students in both groups identified the suggestions as reasons for their participation, and the opposite position was residual. On the other hand, it was observed that the professional education group was more homogeneous in their answers. In contrast, the answers for the regular education group were more divided among the available options.

Table 4 presents the values resulting from Fisher's exact test. For all items, the p-value obtained was $p<0.01$. Moreover, sufficient evidence indicates that the type of education influenced the reasons that led students to participate in the physical education class. When applying the Cramer test, values greater than 0.5 were obtained in the first four items, which indicated a strong association between the groups. For the fifth item, the association between groups was moderate.

The data presented in Table 5 relates to the second question, 'I like physical education classes when:'. For this question, it is evident that the two groups were not in agreement. Regular education students liked physical education classes more when they 'learn a new skill' (50\% strongly agreed; $45 \%$ agreed), while professional education students gave more importance to the item 'move my body' $(66.7 \%$ strongly agreed; $23.8 \%$ agreed). The factor that regular education students valued least was 'what I learn makes me want to practice more'-30\% of students did not agree with this item. The factor that professional education students valued least was 'activities give me pleasure'. Although $47.6 \%$ of professional education students strongly agreed with this item, $14.3 \%$ of them disagreed.

When Fisher's exact test was applied, there was insufficient evidence to indicate that the type of education influences what students liked most in physical education classes ( $p>0.01$ ) (Table 6). Upon applying the Cramer test, values between 0.1 and 0.3 were obtained for all items, which indicated a weak association between groups.

Table 7 presents values related to aspects that led students to dislike physical education classes. Regarding this third and final question of intrinsic motivation, the primary reason for both types of students not liking physical education classes was that there was not enough time to practice everything they would like; overall, $55 \%$ of students in regular education and $66.7 \%$ of students in professional education 'strongly agreed' or 'agreed'.

When Fisher's exact test was applied, it was found that in all items, the value was $p>0.01$ (Table 8), so it can be said that there was not enough evidence to indicate that the type of education influenced what they least like in physical education classes. With the application of the Cramer's test, it was found that the association between groups was weak since the values obtained were comprised between 0.1 and 0.3 except for the second item, which obtained a value above 0.3 , which allowed to conclude a moderate association between the groups.

\subsection{Extrinsic motivation survey}

As presented in Table 9, the results obtained for the first question (B1) indicate that both types of students agreed that the strongest factor influencing them to participate in physical education classes was the desire to get good grades; however, 1 (4.8\%) professional education student did not agree, while 2 (10\%) regular education students also did not agree. Furthermore, a factor that all students disagreed with was 'my performance is better than that of my colleagues. For this point, students assigned less value to their performance being better than that of their colleagues. Overall, 76.2 and $90 \%$ of professional and regular education students disagreed with this item, respectively.

Based on the application of Fisher's exact test, $p$ values $>0.01$ were verified (Table 10); therefore, there was insufficient evidence to indicate that the type of education influenced the extrinsic reasons for participating in physical education classes. In applying Cramer's $V$ test, values between 0.3 and 0.5 were obtained for all items, which indicated a moderate association between groups.

Regarding the second question (B2) presented in Table 11, the extrinsic reason that most students enjoyed physical education classes differed for the two types of education. Regular education students assigned more importance to their opinions being accepted (80\% agreed), while professional education students assigned more importance when they felt integrated into the class ( $90.5 \%$ agreed). Being better than colleagues was the weakest motivator for students to enjoy classes. Notably, this result was similar for both types of education. 
Table 9. Values of relative and absolute frequencies for the question 'B1. I participate in physical education classes because:'.

\begin{tabular}{|c|c|c|c|c|c|c|}
\hline Items & 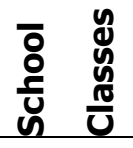 & $\begin{array}{l}\text { Strongly } \\
\text { Agree }\end{array}$ & Agree & $\begin{array}{l}\text { I am in } \\
\text { Doubt }\end{array}$ & Disagree & $\begin{array}{l}\text { Strongly } \\
\text { Disagree }\end{array}$ \\
\hline \multirow{2}{*}{$\begin{array}{l}\text { 1. It is part of the school } \\
\text { subjects. }\end{array}$} & $\mathrm{R}$ & $3(15 \%)$ & $11(55 \%)$ & $2(10 \%)$ & $1(5 \%)$ & $3(15 \%)$ \\
\hline & $P$ & $10(47.6 \%)$ & $8(38.1 \%)$ & $1(4.8 \%)$ & $2(9.5 \%)$ & 0 \\
\hline \multirow{2}{*}{ 2. I'm with my friends. } & $\mathrm{R}$ & $5(25 \%)$ & $13(65 \%)$ & $1(5 \%)$ & 0 & $1(5 \%)$ \\
\hline & $P$ & $8(38.1 \%)$ & $7(33.3 \%)$ & $3(14.3 \%)$ & $3(14.3 \%)$ & 0 \\
\hline \multirow{2}{*}{$\begin{array}{l}\text { 3. My parents income is } \\
\text { greater than that of } \mathrm{my} \\
\text { colleagues. }\end{array}$} & $\mathrm{R}$ & 0 & $2(10 \%)$ & $7(35 \%)$ & $6(30 \%)$ & $5(25 \%)$ \\
\hline & $\mathrm{P}$ & $2(9.5 \%)$ & $3(14.3 \%)$ & $8(38.1 \%)$ & $7(33.3 \%)$ & $1(4.8 \%)$ \\
\hline \multirow{2}{*}{$\begin{array}{l}\text { 4. I want to get good } \\
\text { grades. }\end{array}$} & $\mathrm{R}$ & $4(20 \%)$ & $14(70 \%)$ & $1(5 \%)$ & 0 & $1(5 \%)$ \\
\hline & $P$ & $13(61.9 \%)$ & $7(33.3 \%)$ & $1(4.8 \%)$ & 0 & 0 \\
\hline
\end{tabular}

Note: $\mathrm{R}=$ Regular; $\mathrm{P}=$ Professional

Table 10. Values of Fisher's exact test and Cramer's V for the question 'B1. I participate in physical education classes because:'.

\begin{tabular}{lll}
\hline & Fisher's p-value & Cramer's V \\
\hline 1. It is part of the school subjects. & .076 & .439 \\
\hline 2. I'm with my friends. & .104 & .427 \\
\hline 3. My parents' income is greater than that of my colleagues. & .343 & .349 \\
\hline 4. I want to get good grades. & .014 & .444 \\
\hline
\end{tabular}

Table 11. Values of relative and absolute frequencies for the question 'B2. I like physical education classes when:'.

\begin{tabular}{|c|c|c|c|c|c|c|}
\hline Items & 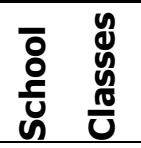 & $\begin{array}{l}\text { Strongly } \\
\text { Agree }\end{array}$ & Agree & $\begin{array}{l}\text { I am in } \\
\text { Doubt }\end{array}$ & Disagree & $\begin{array}{l}\text { Strongly } \\
\text { Disagree }\end{array}$ \\
\hline \multirow{2}{*}{$\begin{array}{l}\text { 1. I forget about the other } \\
\text { classes. }\end{array}$} & $\mathrm{R}$ & $6(30 \%)$ & $4(20 \%)$ & $2(10 \%)$ & $6(30 \%)$ & $2(10 \%)$ \\
\hline & $P$ & $10(47.6 \%)$ & $5(23.8 \%)$ & $5(23.8 \%)$ & $1(4.8 \%)$ & 0 \\
\hline \multirow{2}{*}{$\begin{array}{l}\text { 2. The teacher and/or } \mathrm{my} \\
\text { colleagues recognise } \mathrm{my} \\
\text { performance. }\end{array}$} & $\mathrm{R}$ & $3(15 \%)$ & $10(50 \%)$ & $4(20 \%)$ & 0 & $3(15 \%)$ \\
\hline & $\mathrm{P}$ & $8(38.1 \%)$ & $8(38.1 \%)$ & $2(9.5 \%)$ & $3(14.3 \%)$ & 0 \\
\hline \multirow{2}{*}{$\begin{array}{l}\text { 3. I feel integrated into the } \\
\text { class. }\end{array}$} & $\mathrm{R}$ & $6(30 \%)$ & $9(45 \%)$ & $2(10 \%)$ & $2(10 \%)$ & $1(5 \%)$ \\
\hline & $P$ & $9(42.9 \%)$ & $10(47.6 \%)$ & $1(4.8 \%)$ & $1(4.8 \%)$ & 0 \\
\hline \multirow{2}{*}{ 4. My opinions are accepted. } & $\mathrm{R}$ & $4(20 \%)$ & $12(60 \%)$ & $1(5 \%)$ & 0 & $3(15 \%)$ \\
\hline & $P$ & $6(28.6 \%)$ & $10(47.6 \%)$ & $4(19 \%)$ & $1(4.8 \%)$ & 0 \\
\hline \multirow{2}{*}{$\begin{array}{l}\text { 5. I'm better than my } \\
\text { colleagues. }\end{array}$} & $\mathrm{R}$ & $1(5 \%)$ & $2(10 \%)$ & $2(10 \%)$ & $6(30 \%)$ & $9(45 \%)$ \\
\hline & $P$ & $1(4.8 \%)$ & $4(19 \%)$ & $7(33.3 \%)$ & $8(38.1 \%)$ & $1(4.8 \%)$ \\
\hline
\end{tabular}

Note: $\mathrm{R}=$ Regular; $\mathrm{P}=$ Professional. 
Table 12. Values of Fisher's exact test and Cramer's V in the question 'B2. I like physical education classes when:'.

\begin{tabular}{lcc}
\hline & Fisher's p-value & Cramer's V \\
\hline 1. I forget about the other classes. & .096 & .440 \\
\hline 2. The teacher and/or my colleagues recognise my performance. & .059 & .472 \\
\hline 3. I feel integrated into the class. & .720 & .237 \\
\hline 4. My opinions are accepted. & .188 & .394 \\
\hline 5. I'm better than my colleagues. & .023 & .497 \\
\hline
\end{tabular}

Table 13. Values of relative and absolute frequencies for the question 'B3. I don't like physical education classes when:'.

\begin{tabular}{|c|c|c|c|c|c|c|}
\hline Items & $\begin{array}{ll}\overline{0} & y \\
\vdots & y \\
\frac{5}{0} & \frac{1}{v} \\
\text { u }\end{array}$ & $\begin{array}{l}\text { Strongly } \\
\text { Agree }\end{array}$ & Agree & $\begin{array}{l}\text { I am in } \\
\text { Doubt }\end{array}$ & Disagree & $\begin{array}{l}\text { Strongly } \\
\text { Disagree }\end{array}$ \\
\hline \multirow{2}{*}{$\begin{array}{l}\text { 1. I don't feel integrated into } \\
\text { the class. }\end{array}$} & $\mathrm{R}$ & $4(20 \%)$ & $9(45 \%)$ & $2(10 \%)$ & $3(15 \%)$ & $2(10 \%)$ \\
\hline & $\mathrm{P}$ & $3(14.3 \%)$ & $5(23.8 \%)$ & $8(38.1 \%)$ & $3(14.3 \%)$ & $2(9.5 \%)$ \\
\hline \multirow{2}{*}{$\begin{array}{l}\text { 2. I don't sympathize with the } \\
\text { teacher. }\end{array}$} & $\mathrm{R}$ & $3(15 \%)$ & $6(30 \%)$ & $2(10 \%)$ & $4(20 \%)$ & $5(25 \%)$ \\
\hline & $P$ & $1(4.8 \%)$ & $7(33.3 \%)$ & $4(19 \%)$ & $5(23.8 \%)$ & $4(19 \%)$ \\
\hline \multirow{2}{*}{$\begin{array}{l}\text { 3. The teacher compares my } \\
\text { performance with that of } \\
\text { another colleague. }\end{array}$} & $\mathrm{R}$ & $5(25 \%)$ & $7(35 \%)$ & $2(10 \%)$ & $2(10 \%)$ & $4(20 \%)$ \\
\hline & $\mathrm{P}$ & $3(14.3 \%)$ & $6(28.6 \%)$ & $6(28.6 \%)$ & $3(14,3 \%)$ & $3(14,3 \%)$ \\
\hline \multirow{2}{*}{$\begin{array}{l}\text { 4. My colleagues laugh at my } \\
\text { failures. }\end{array}$} & $\mathrm{R}$ & $3(15 \%)$ & $8(40 \%)$ & $3(15 \%)$ & $3(15 \%)$ & $3(15 \%)$ \\
\hline & $\mathrm{P}$ & $2(9,5 \%)$ & $7(33,3 \%)$ & $3(14,3 \%)$ & $6(28,6 \%)$ & $3(14,3 \%)$ \\
\hline \multirow{2}{*}{$\begin{array}{l}\text { 5. Some colleagues want to } \\
\text { demonstrate that they are } \\
\text { better than others. }\end{array}$} & $\mathrm{R}$ & $7(35 \%)$ & $8(40 \%)$ & $1(5 \%)$ & $2(10 \%)$ & $2(10 \%)$ \\
\hline & $\mathrm{P}$ & $3(14,3 \%)$ & $10(47,6 \%)$ & $3(14,3 \%)$ & $4(19 \%)$ & $1(4,8 \%)$ \\
\hline \multirow{2}{*}{ 6. Obtaining low grades. } & $\mathrm{R}$ & $3(15 \%)$ & $8(40 \%)$ & $3(15 \%)$ & $4(20 \%)$ & $2(10 \%)$ \\
\hline & $\mathrm{P}$ & $3(14.3 \%)$ & $2(9.5 \%)$ & $2(9.5 \%)$ & $11(52.4 \%)$ & $3(14.3 \%)$ \\
\hline \multirow{2}{*}{$\begin{array}{l}\text { 7. My faults make me not look } \\
\text { like a good student to the } \\
\text { teacher. }\end{array}$} & $\mathrm{R}$ & $2(10 \%)$ & $6(30 \%)$ & $3(15 \%)$ & $6(30 \%)$ & $3(15 \%)$ \\
\hline & $\mathrm{P}$ & $5(23.8 \%)$ & $3(14.3 \%)$ & $6(28.6 \%)$ & $5(23.8 \%)$ & $2(9.5 \%)$ \\
\hline
\end{tabular}

Note: $\mathrm{R}=$ Regular; $\mathrm{P}=$ Professional.

Table 14. Values of Fisher's exact test and Cramer's $V$ for the question 'B3. I don't like physical education classes when:'.

\begin{tabular}{lll}
\hline & $\begin{array}{l}\text { Fisher's } \\
\text { value }\end{array}$ & $\begin{array}{l}\mathbf{p}- \\
\text { V } \\
\text { Cramer }\end{array}$ \\
\hline 1. I don't feel integrated into the class. & .308 & .344 \\
\hline 2. I don't sympathise with the teacher. & .849 & .218 \\
\hline 3. The teacher compares my performance with that of another .634 & .266 \\
\hline
\end{tabular}


colleague.

4. My colleagues laugh at my failures.

.882

.174

5. Some colleagues want to demonstrate that they are better than others.

.489

.124

.494

7. My faults make me not look like a good student to the teacher.

When Fisher's exact test was applied, $\mathrm{p}>0.01$ (Table 12) values were verified in all items; thus, there was insufficient evidence to indicate that the type of education influenced the extrinsic reasons why students liked physical education classes. The Cramer test results suggest a moderate association between groups since the obtained values were between 0.3 and 0.5 , except for the third item, which obtained one point below and thus resulted in a weak association between groups.

In Table 13, the data presented for the third question (B3) of extrinsic motivation revealed that regular education students did not like physical education classes when they were not integrated into the class ( $65 \%$ of students). In contrast, professional education pointed out that the main reason why they did not like physical education classes was that some colleagues wanted to demonstrate that they were better than others $(61.9 \%$ of students). The least important factor among regular education students was 'my failures make it not look good for the teacher', with $45 \%$ (regular) and $33.3 \%$ (professional) of students disagreeing. The least important factor among regular education students was obtaining low grades $(66.7 \%)$. Notably, in the first question, since they want to get grades, they attributed a lot of value to participating in classes.

For the same point, Fisher's exact test presented values of $p>0.01$ (Table 14); thus, there was insufficient evidence to indicate that the type of education influenced the extrinsic reasons for students not liking physical education class. Upon application of the Cramer test, it was found that the association between groups was weak since the values obtained were between 0.1 and 0.4 -except for the sixth item, which obtained a value between 0.3 and 0.5 , suggesting a moderate association between the groups.

The main objective of this study was to determine the most and least important reasons for both the intrinsic and extrinsic motivation of students in physical education classes. Additionally, it sought to compare intrinsic and extrinsic motivation between regular and professional education students based on responses to the questionnaire applied in this study.

The main conclusions of this study were that motivation was mainly intrinsic in both types of education analysed (i.e., regular and professional). Questions 1 and 2 of the questionnaire adapted from Kobal [31] intended to determine why students like and participate in physical education classes. Through items related to these questions, evidence of intrinsic motives influencing students' motivation was observed (based on the frequency of answers provided). Previous studies $[35,36]$ have reported that a variety of proposals encourages more pleasure and motivation to learn and that an individual's motivational predisposition varies according to their internal and external influences. As such, the intrinsic influence is fundamental for obtaining pleasure while performing physical activity, regardless of context. The results reveal that the participation of students was based on their intrinsic motivation since they practice exercises because they like physical activity. Moreover, they particularly liked it when they learned a new skill.

\subsection{Intrinsic motivation}

The results obtained were nearly identical for both education types in the first two questions (A1 and A2) related to intrinsic motivation (Table 6). The observed data suggest that both education types revealed that students value most in class to increase their knowledge about sports and other content. Overall, 75 and $100 \%$ of regular and professional educations agreed with this reason (see Table 3 ).

Based on the analysis of the data from the second question (A2) (Table 5), students of both education types liked physical education classes when they acquired a new skill. Thus, teachers should seek to diversify, dynamize and innovate their classes since these are factors to which students respond positively 
and motivate them to attend and enjoy physical education classes.

These results are in line with the results of previous investigations $[37,38]$, inferring that students attach great importance to physical activities and associate them with quality of life as well as better physical and psychological development. Another investigation [39] also emphasised the importance of intrinsic motivation by noting that personal satisfaction is linked to intrinsic motivation is considered a challenge that students face when tasks are assigned to them.

However, although both types of education are primarily motivated by intrinsic factors, differences exist between regular and professional education responses regarding appreciation of the reasons addressed in question A2 (Table 5). In this case, regular education students assigned greater importance to accepting their opinions, while professional education students assigned greater importance to the fact that they felt integrated into the class. However, both types of education converged by not assigning much importance to be better than their colleagues, which is verified by the residual value of responses.

According to the results obtained in the third question (A3) (Table 7), students under both education types indicated that their main reason for not liking physical education classes did not have enough time to practice everything they would like (55 and 66.7\% for regular and professional education students, respectively). Regarding this item, it is up to the teacher to organise strategically and increase the task time (regardless of the modality to be taught) so that classes are dynamic and have few breaks. This would allow students to become motivated, feel that the class was useful and consider their participation to be positive. Students from both education types did not like physical education because they performed too little exercise. Therefore, it can be concluded that students did not attach importance to the fact that they were not encouraged during physical education class.

It was also found that the present study results support a relationship between intrinsic motivation and motivational climate that was previously reported in other studies. Regarding the motivational determinants of pleasure and interest, engaging in physical education presents itself as an effective method to improve personal well-being since it favours a motivation that focuses on selfimprovement, personal benefit and continuous development $[40,41]$.

However, previous research [42] has suggested that task orientation is related to intrinsic motivation that can be weakened by one's ego. Another investigation [43] noted that the motivational climate oriented toward learning is compatible with the satisfaction of basic psychological needs and autonomous motivation since contexts of this nature promote success criteria that are more heavily focused on the subject and associated with increased intrinsic motivation.

\subsection{Extrinsic motivation}

Although both types of education are primarily motivated by intrinsic factors, the results suggest that both types converge on obtaining good grades as the main reason for participating in physical education classes. The percentages of support for this factor were 90 and $95.2 \%$ for regular and professional education students, respectively. Regarding participation in physical education classes, the extrinsic agreement between the two teaching modalities in terms of the importance of grades was also verified in the agreement of the discipline as part of the school curriculum and the importance attributed to social relations, which had previously been emphasised [44]. In this way, the high importance of grades-as an extrinsic motivation assumed by both education types-contradicts the importance of a positive grade (attributed to school success by students) due to the appraisal of learning being socially valued based on numbers [45] within the scope of school curriculums and physical education classes. On the other hand, it appears that professional education students presented higher values for question 3 'I don't like physical education classes when I get low marks' (B3.6). Thus, professional education students feel extrinsically motivated to participate in physical education classes when they have high marks.

Regarding items related to extrinsic motivation in question 2 (B2), some disparities were observed for the reason that led students to enjoy physical education classes. Regular education students valued their opinions being accepted (80\% agreed), while professional education students valued when they felt integrated into the class ( $90.5 \%$ agreed). These were the main reasons that led students to enjoy physical education classes. Notably, students in both education 
types exhibited a low percentage of agreement with the answer 'I am better than my colleague'. Overall, $75 \%$ of regular education students disagreed that this item encourages them to enjoy physical education classes, while $42.9 \%$ of professional students disagreed and another $33.3 \%$ were in doubt. In question 3 (B3), differences were observed in the reasons that the two types of students assigned value to. Regular education students assigned more importance to the item 'I do not feel integrated into the class', which prevents regular education students from liking physical education classes. This result suggests that regular education students placed greater value on interpersonal relationships as a determining factor in their overall interest in this discipline. On the other hand, professional education students highlighted the importance of some colleagues demonstrating that they are better than others. Once again, this shows concern for interpersonal relationships (as per regular education students. The factor with the lowest level of relevance for regular education was students appearing good to the teacher; however, $55 \%$ agreed with this item. According to a previous study [41], the achievement indicators, which are not oriented towards one's ego, lead to a lower perception of competence. Therefore, these indicators tend to become fragile at the motivational level and exhibit negative or maladaptive behavioural responses (e.g., less commitment and persistence in achievement, less commitment to the activity and greater performance anxiety). A previous study also considered [46] that the perception of competence in learning physical activities is an element that influences one's interest and persistence in a task. The possible limitations of this study are the number of participants, and the fact that all students belong to the same school.

\section{Conclusion}

This work aimed to determine the most and least important reasons for the intrinsic and extrinsic motivation of students in physical education classes. After presenting and discussing the results in light of the study objectives, it was concluded that both regular and professional education students were intrinsically and extrinsically motivated to engage in physical education classes. In this way, both education types had high frequencies and proportions of intrinsic motivation compared to extrinsic motivation. Notably, professional education students showed higher agreement values when compared to the results of regular education students. According to the investigated theme and intended objectives, it was possible to observe minor differences between the two education types. For example, professional education students were more motivated and predisposed to attend physical education classes due to both intrinsic and extrinsic global motivational factors.

Furthermore, it was evident that professional education students were generally more predisposed and motivated to practice physical education classes because they typically liked physical activities, enjoyed classes and considered it important to increase knowledge about sports and other content. However, while regular education students also agreed that increasing knowledge about sports was important, they did not feel as motivated to participate in physical education classes as professional education. Regarding extrinsic motivation, students in professional education placed more importance on physical education being included in school subjects and wanting to get good grades compared to regular education students. The factor that regular education students placed more importance on was interpersonal relationships in the classroom. Students from both education types highlighted the relevance of the performance factor in different ways. For example, students in professional education sought to improve performance and the achievement of good grades, while students in regular education were concerned with performing tasks for personal satisfaction (i.e., intrinsic motivation). According to the results, the present study indicates that there may be implications for teaching planning units and annual class plans. Thus, in light of the results, there seems to be evidence that the physical education teacher should guide the activities according to the curricular plan but also with the motivations revealed by the students, especially in flexible curricular and programmatic contexts. Thus, further investigations are needed, and it should be noted that this research could be replicated in other regions of the world and according to different educational paths (variable, depending on the region analysed). In addition, it would be interesting to investigate, particularly in relation to gender, whether there is a motivational trend towards the practice of physical education in different educational pathways.

\section{References}

[1] R. Bailey, Physical education and sport in schools: A review of benefits and outcomes, 
Journal of School Health, 76 (2006) 397-401. [DOI] | [PubMed]

[2] B.W. Landry, S.W. Driscoll, Physical activity in children and adolescents, PM\&R, 4 (2012) 826-832. [DOI] | [PubMed]

[3] I. Janssen, A.G. LeBlanc, Systematic review of the health benefits of physical activity and fitness in school-aged children and youth, International Journal of Behavioral Nutrition and Physical Activity, 7 (2010) 40. [DOI] । [PubMed]

[4] P.D. Loprinzi, B.J. Cardinal, K.L. Loprinzi, H. Lee, Benefits and environmental determinants of physical activity in children and adolescents, Obesity Facts, 5 (2012) 597-610. [DOI] । [PubMed]

[5] D. Dudley, A. Okely, P. Pearson, W. Cotton, A systematic review of the effectiveness of physical education and school sport interventions targeting physical activity, movement skills and enjoyment of physical activity, European Physical Education Review, 17 (2011) 353-378. [DOI]

[6] W. Kay, Physical Education-Quality: A quality experience for all pupils, URL (Consulted 13 October 2006).

[7] D. Kirk, Physical education, youth sport and lifelong participation: the importance of early learning experiences, European Physical Education Review, 11 (2005) 239-255. [DOI]

[8] R. Trigueros, L.A. Mínguez, J.J. GonzálezBernal, M. Jahouh, R. Soto-Camara, J.M. Aguilar-Parra, Influence of teaching style on physical education adolescents' motivation and health-related lifestyle, Nutrients, 11 (2019) 2594. [DOI] | [PubMed]

[9] S. de Araújo, T. Mesquita, A. Araújo, A. de Bastos, Motivação nas aulas de educação física: um estudo comparativo entre gêneros, EFDeportes com, Revista Digital. Buenos Aires, Ano, 13 (2008).

[10] R.A. Kusurkar, T.J. Ten Cate, C.M.P. Vos, P. Westers, G. Croiset, How motivation affects academic performance: a structural equation modelling analysis, Advances in Health Sciences Education, 18 (2013) 57-69. [DOI] [PubMed]
[11] A. Marques, F. Gómez, J. Martins, R. Catunda, $H$. Sarmento, Association between physical education, school-based physical activity, and academic performance: a systematic review, Retos, 31 (2017) 316-320.

[12] A.A. Lourenço, M.O.A. De Paiva, A motivação escolar e o processo de aprendizagem, Ciências \& Cognição, 15 (2010).

[13] M.J. Balancho, F. Coelho, Motivar os alunoscriatividade na relação pedagógica: conceitos e práticas (3aEdição), Lisboa: Texto Editora, Lda, (2001).

[14] E.L. Deci, R.M. Ryan, Intrinsic motivation, The Corsini Encyclopedia of Psychology, (2010) 12. [DOI]

[15] R.M. Ryan, E.L. Deci, Self-determination theory and the facilitation of intrinsic motivation, social development, and well-being, American Psychologist, 55 (2000) 68-78. [DOI] । [PubMed]

[16] X. Montserrat, Como motivar-Dinâmicas para o sucesso, Edições, Porto, (2006).

[17] Y.D.R. Santos, Motivar para praticar: fatores de motivação intrínseca e extrínseca dos alunos nas aulas de educação física, Educação Fisica Licenciatura-Tubarão, (2019) 1-15.

[18] D.R. Schwaab, Motivação intrínseca e extrínseca nas aulas de educação física, (2014).

[19] M.C. Kobal, Motivação intrínseca e extrínseca nas aulas de educação física, (1996).

[20] F.M.G. Oliveira, Estudo da força em alunos do 110 ano sujeitos a intervenção: relatório de estágio, University São Paulo, Ribeirão Preto, 2019.

[21] M.R. Lepper, J.H. Corpus, S.S. Iyengar, Intrinsic and extrinsic motivational orientations in the classroom: Age differences and academic correlates, Journal of Educational Psychology, 97 (2005) 184-196. [DOI]

[22] N. Gillet, R.J. Vallerand, M.-A.K. Lafrenière, Intrinsic and extrinsic school motivation as a function of age: The mediating role of autonomy support, Social Psychology of Education, 15 (2012) 77-95. [DOI]

[23] V. Scherrer, F. Preckel, Development of motivational variables and self-esteem during 
the school career: A meta-analysis of longitudinal studies, Review of Educational Research, 89 (2019) 211-258. [DOI]

[24] T. Gnambs, B. Hanfstingl, The decline of academic motivation during adolescence: An accelerated longitudinal cohort analysis on the effect of psychological need satisfaction, Educational Psychology, 36 (2016) 1691-1705. [DOI]

[25] F.A. Teixeira, A.F. Moletta, Motivação nas aulas de Educação Física, Anais Do $X$ Encontro Nacional de Educação-EDUCERE. Pontifícia Universidade Católica Do Paraná-PUC, Curitiba, (2011).

[26] S.C. Darido, A educação física na escola e o processo de formação dos não praticantes de atividade física, Revista Brasileira de Educação Física e Esporte, 18 (2004) 61-80.

[27] A. Pires, L. Cid, C. Chicau Borrego, J. Alves, C. Silva, Preliminary validation of a questionnaire to measure basic psychological needs in Physical Education, Motricidade, 6 (2010) 3351. [DOI]

[28] A. Papaioannou, D. Milosis, C. Gotzaridis, Interdisciplinary teaching of physics in physical education: Effects on students' autonomous motivation and satisfaction, Journal of Teaching in Physical Education, 39 (2020) 156-164. [DOI]

[29] A.G. Papaioannou, Teaching a holistic, harmonious and internal motivational concept of excellence to promote olympic ideals, health and well-being for all, Journal of Teaching in Physical Education, 36 (2017) 353-368. [DOI]

[30] E.T. Leptokaridou, S.P. Vlachopoulos, A.G. Papaioannou, Experimental longitudinal test of the influence of autonomy-supportive teaching on motivation for participation in elementary school physical education, Educational Psychology, 36 (2016) 1135-1156. [DOI]

[31] M.N. Meira, W.V.S. Leal, C.R. Ferreira, Motivação de professores e alunos nas aulas de educação física em uma escola pública da cidade de montes claros-mg, Revista Bionorte, 7 (2018).

[32] S. Zach, M. Bar-Eli, T. Morris, M. Moore, Measuring motivation for physical activity: An exploratory study of PALMS - the physical activity and leisure motivation scale, Athletic Insight: The Online Journal of Sport Psychology, 4(2012), 141-154.

[33] P. Kline, The handbook of psychological testing, 2nd ed, Taylor \& Frances/Routledge, Florence, KY, US, (1993).

[34] J. Cohen, Statistical Power Analysis for the Behavioral Sciences, Academic press, (1988). [DOI]

[35] C.L. Bryan, M.A. Solmon, Student motivation in physical education and engagement in physical activity, Journal of Sport Behavior, 35(2012), 267-285.

[36] L. Aleksovska-Velickovska, S. Gontarev, K. Ruzdija, Students motivation for engaging in physical activity: Theory for self-determination, Journal of Human Sport and Exercise, 14 (2019) 325-334. [DOI]

[37] X. Gu, M. Chang, M.A. Solmon, Physical activity, physical fitness, and health-related quality of life in school-aged children, Journal of Teaching in Physical Education, 35 (2016) 117-126. [DOI]

[38] A. Baena-Extremera, J.A. Sanchez-Fuentes, A. Granero-Gallegos, F.J. Perez-Quero, C. BrachoAmador, Motivation and motivational climate as predictors of perceived importance of physical education in Spain, South African Journal for Research in Sport, Physical Education and Recreation, 35 (2013) 1-13.

[39] P. Xiang, B. Ağbuğa, J. Liu, R.E. McBride, Relatedness need satisfaction, intrinsic motivation, and engagement in secondary school physical education, Journal of Teaching in Physical Education, 36 (2017) 340-352. [DOI]

[40] G. González Valero, F. Zurita Ortega, A. Martínez Martínez, Panorama motivacional y de actividad física en estudiantes: una revisión sistemática, Education, Sport, Health and Physical Activity (ESHPA), 1 (2017) 41-58.

[41] G. González-Valero, J.L. Ubago-Jiménez, I.A. Ramírez-Granizo, P. Puertas-Molero, Association between motivational climate, adherence to mediterranean diet, and levels of physical activity in physical education students, Behavioral Sciences, 9 (2019) 37. [DOI] । [PubMed] 
[42] E.L. Deci, R.M. Ryan, Self-Determination Theory, Handbook of Theories of Social Psychology: Collection: Volumes 1 \& 2, (2011) 416.

[43] L. Cid, A. Pires, C. Borrego, P. Duarte-Mendes, D.S. Teixeira, J.M. Moutão, D. Monteiro, Motivational determinants of physical education grades and the intention to practice sport in the future, Plos One, 14 (2019) e0217218. [DOI] | [PubMed]

[44] M.H. McDonough, S. Ullrich-French, M.L. McDavid, Helping kids connect: Participant and staff perspectives on facilitating social relationships in a physical activity-based positive youth development program for youth from low-income families, Sport, Exercise, and Performance Psychology, 7 (2018) 13-29. [DOI]

[45] K. Casebolt, L.-M. Chiang, B. Melton, J. Russell, College/university instructional physical activity programs and academic success in higher education, International Journal of Kinesiology in Higher Education, 1 (2017) 100-106. [DOI]

[46] C.D. Ennis, Educating students for a lifetime of physical activity: Enhancing mindfulness, motivation, and meaning, Research Quarterly for Exercise and Sport, 88 (2017) 241-250. [DOI] | [PubMed]

\section{Acknowledgement}

The authors thanks all students and teachers that allow the development of this study.

\section{Funding}

This research was funded by the Portuguese Foundation for Science and Technology, I.P., grant number UID/DTP/04045/2020

\section{Authors contribution}

All the authors equally contributed and approved the final version of the article.

\section{Ethics Approval}

The ethics approval was sought from Institutional ethics committee

Informed consent

Written consent was obtained from the participants

\section{Conflict of interest}

The authors declare no conflict of interest

\section{Does this article screened for similarity} Yes

\section{About The License}

(c) The author(s) 2021. The text of this article is open access and licensed under a Creative Commons Attribution 4.0 International License 